\title{
Improving the perception of intelligence: a short intervention for Secondary School Students
}

\author{
Elena Medina-Garrido ${ }^{1}$ and Jaime León ${ }^{2}$ \\ ${ }^{1}$ Consejería de Educación, Gobierno de Canarias, Las Palmas \\ ${ }^{2}$ Departamento de Educación, Universidad de Las Palmas de Gran Canaria, \\ Las Palmas
}

\section{Spain}

Correspondence: Jaime León. Departamento de Educación. Universidad de Las Palmas de Gran Canaria. C/Santa Juana de Arco, 1. 35004-Las Palmas. Spain. E-mail: jaime.leon@ulpgc.es

(C) Education \& Psychology $\mathrm{I}+\mathrm{D}+\mathrm{i}$ and Ilustre Colegio Oficial de la Psicología de Andalucía Oriental (Spain) 


\begin{abstract}
Introduction. Holding a fix or an incremental mindset influence academic performance, we wonder if an intervention would change students' mindsets. The main goal of this study was to design and analyse the effectiveness of an easy to scale intervention to diminish students' belief about intelligence as something innate and fix, and think that we all have an intellectual potential that depends on ourselves to work it and, thus, maximize our performance.
\end{abstract}

Method. The program was designed following the guidelines of brief interventions, because of their numerous benefits, and it was tested with students from first year of Compulsory Secondary Education. To test its efficacy, we ran a study comparing an experimental and control group with one prior and two post-intervention assessments.

Results. We observed using a multilevel model that the trajectory of the experimental group was different from the control group, obtaining evidence that students in the experimental group decreased their beliefs about intelligence as something fix.

Discussion and Conclusion. This work may serve as a starting point for future work to improve academic performance in a simple, easily replicable and scalable way.

Keywords: mindsets, motivation, intervention, experimental design, secondary education. 


\section{Resumen}

Introducción. En Educación Secundaria es frecuente encontrarse con alumnos que piensan que tal vez no sean lo suficientemente inteligentes como para superar con éxito esta etapa educativa. Pensar en la inteligencia como algo fijo o modificable influye en el rendimiento académico, por lo que nos preguntamos si una intervención breve puede cambiar las ideas del alumnado sobre su inteligencia. El objetivo principal de esta investigación fue diseñar y analizar la eficacia de una intervención, para que el alumnado piense que la inteligencia no es algo innato e inmodificable, sino que todos tenemos un potencial intelectual y que depende de nosotros mismos trabajar para desarrollarlo.

Método. El programa se diseñó siguiendo los principios de las intervenciones breves, y se llevó a cabo con alumnos de $1^{\circ}$ de Educación Secundaria Obligatoria. Para analizar su eficacia se realizó un estudio con grupo cuasi-experimental y de cuasi-control, con una evaluación previa y dos posteriores a la intervención.

Resultados. Mediante un modelo multinivel se observó que la trayectoria del grupo experimental fue diferente a la del grupo control, obteniendo evidencias de que los alumnos del grupo experimental disminuyeron sus creencias acerca de la inteligencia como algo estable e inmodificable.

Discusión y conclusiones. Este trabajo puede servir como punto de partida para que futuros trabajos mejoren el rendimiento académico de una forma sencilla, replicable y fácilmente escalable.

Palabras Clave: ideas implícitas sobre la inteligencia; desmotivación; intervención; estudio experimental; educación secundaria. 


\section{Introduction}

In Secondary Education, it is frequent to meet students who think that they may not be smart enough to successfully overcome this educational stage (Paunesku et al., 2015; Yeager et al., 2016). Student motivation and engagement decreases when passing from primary to secondary (Davidson, Gest, \& Welsh, 2010; Roeser \& Eccles, 1998). There are several reasons that may explain this fact: there are more students in the classes, students have many different teachers, so the relationship with them is more impersonal and, in addition, the contents of classes are more difficult (Goodenow, 1993). All this leads students to think that they are not smart enough to achieve the required goals (Anderman, 2003; Wentzel, 2009).

This topic has been studied by several authors, Dweck (2006) among them, who, from her mindsets framework, states that there are students who think that their intelligence is fixed, whereas other students think it is something that can be modified. This author with other experts (Blackwell, Trzesniewski, \& Dweck, 2007; Romero, Master, Paunesku, Dweck, \& Gross, 2014), has analyzed how the perception or idea that the students have of their own intelligence is related to the academic performance: the students who think of the intelligence as modifiable obtain better results. In addition, interventions in the USA based on Dweck's framework (1999) have provide evidence that students' mindsets can be modified (Blackwell et al., 2007; Donohoe, Topping, \& Hannah, 2012).

Usually, these interventions have been developed in a short period of time under the paradigm of brief interventions (Walton \& Cohen, 2011; Yeager et al., 2014). Brief interventions have advantages such as ease of application, specific approach to a particular problem, discretion and attribution of improvement to internal causes (Yeager \& Walton, 2011). Even one-session interventions have proven effective in, for example, improving parental style (Lim, Tormshak, \& Dishion, 2005), increase risk awareness of sexually transmitted diseases (Thurstone, Riggs, Klein, \& Mikulich-Gilbertson, 2007) or decrease gender violence (Crane \& Eckhardt, 2013).

\section{Mindsets framework}

What exactly is the theory set forth by Dweck about mindsets? Blackwell, Trzesniewski and Dweck (2007) explain that students can have two visions about the nature of their intelligence: some think that intelligence is something stable, not modifiable and that 
it depends on genetics, and others that it is not stable, but can be improved and depends on learning and effort. However, this does not imply that the latter think that everyone has the same potential: what they think is that each individual can develop his intellectual capacity to the maximum of his own potential (Hong, Chiu, Dweck, Lin, \& Wan, 1999; Inglés et al., 2015). Correlational and experimental studies have shown that these mindsets (fixed and growth) encourage students to think, feel, and behave differently (Rattan, Good, \& Dweck, 2012; Verniers \& Martinot, 2015).

\section{Correlational evidences}

Dweck and Leggett (1988) observed that thinking about intelligence in one way or another is related to motivation and self-regulation. They concluded that those with a growth mindset try to perform tasks that promote the acquisition of intellectual ability, and strive to overcome difficulties, while those with a fixed mindset, when facing a difficulty tend to withdraw.

Researchers has also observed that these two mindsets are related to learning and academic performance. Chen and Pajares (2010) conducted a study in the USA with a sample of 508 first year secondary education students. They found that a growth mindset indirectly predicted scores through a series of self-regulated and motivational variables. Similarly, Luo, Lee, Ng and Wei Ong (2014), in a study with 273 Singapore students (corresponding to Secondary Education in the Spanish educational system), They gathered evidence that thinking about intelligence toward Mathematics as something that can be improved is directly related to seeing the Mathematics classes as something fun and feeling satisfied and inversely related to boredom and worry about failure in class. In addition, these authors observed that the belief in mathematical intelligence as something to be improved predicted performance in the Mathematics subject in two senses: positively, through satisfaction, and negatively, through the concern to fail.

\section{Previous Interventions}

Blackwell et al.(2007) performed an intervention with a sample of 91 students that was divided into an experimental group and a control group. Students were between 12 and 14 years old and were characterized by poor performance in mathematics. The intervention consisted of eight 25-minute sessions in which students were taught that intelligence is can be developed. In particular, the first two sessions taught the anatomy of the brain and the functioning of neurons and neurotransmitters. In the third and fourth sessions, a text entitled 
"how to increase your intelligence" was read and then an activity was carried out on the text. In the next two sessions, stereotypes about gender and race and study techniques were worked on. Finally, in the last two sessions a debate was generated in class on four aspects: 1) the more you learn, the stronger your brain becomes; 2) As you learn, you become more intelligent; 3) To be intelligent depends on oneself; and 4) Using labels like "the nerd" or "the fool" prompts students not to dare to struggle for fear of being "the fool" or "the weird" of the class. It should be noted that sessions one, two, five and six were carried out in both the experimental group and the control group. It was observed that immediately before the intervention the notes in Mathematics had fallen with respect to the spring of the previous course; However, after the intervention the notes of the experimental group stopped decreasing, while those in the control group continued to decrease.

Donohoe et al.(2012) conducted an intervention with a sample of 33 Scottish students aged between 13 and 14, 18 in the experimental group and 15 in the control group. The lead author of the study was a teacher of the group. The intervention was applied using a computer program where students, accompanied by three interactive characters, had to perform a series of activities and challenges. The program was structured in four sessions of 40 minutes: 1) about the basic aspects of the brain; 2) about the behavior of the brain; 3) about the development of the brain, and 4) about brain stimulants. They observed that the control group did not change their mindset, whereas the experimental group did, but three months after the intervention their mindsets happened to be similar to the initial one.

\section{Brief interventions}

As already mentioned, in the educational context, brief interventions have a number of advantages such as: a) being easy to apply, b) being directed only to the problem to be improved, c) being more discreet, because the students do not have to go to extraordinary classes or have a support tutor, so they will not feel the stigma of "being a bad student" and d) get the student to explain their improvement for internal reasons rather than for external such as extraordinary classes or teacher support (Yeager, Walton, \& Cohen, 2013).

The purpose of these interventions is not to deepen academic content or study techniques, but rather to work on the thoughts, feelings and beliefs of students (Lazowski \& Hulleman, 2016; Spitzer \& Aronson, 2015). This type of intervention has aroused the mistrust of some educational professionals, however, several researchers who have applied brief 
interventions have observed very positive effects on academic performance (Aronson, Fried, \& Good, 2002; Cohen, Garcia, Purdie-Vaughns, Apfel \& Brzustoski, 2009). Some examples of effective short interventions are those of Hulleman and Harackiewicz (2009) and Morisano, Hirsh, Peterson, Pihl, and Shore (2010). Hulleman and Harackiewicz (2009), based on the expectancy-value theory (Eccles, 1983; Wigfield and Eccles, 2000), performed an experimental study with random assignment (control group: $\mathrm{n}=126$; experimental group: $\mathrm{n}=$ 136). During a semester, all the students had to do a brief work about the science subject every three or four weeks; The difference was that those in the experimental group had to write about what class contents could use outside class, while those in the control group had to summarize what they had done in class. The researchers observed an improvement in the scores of students in the experimental group versus those in the control group.

Morisano et al. (2010), based on the goal-setting model (Locke and Latham, 1990, 2002), analyzed the efficacy of an intervention that sought for university students to set clear and specific objectives. To carry out the intervention, the students $(n=45)$ needed to access an online platform. They were given a series of instructions so that they could establish concrete objectives. The researchers observed that, compared to the control group, students in the experimental group scored higher.

Finally, it is interesting brief intervention conducted by a teacher on the first day of classes to improve motivation of university students (McGinley and Jones, 2014). The experimental group consisted of students of two classes, 14 first-year students and 39 fourthyear students. The intervention began by dividing the class into groups and making them discuss the usefulness and interestingness of the subject. In addition, the teacher responded to questions asked by the students and learned their names. Results were positive, authors gathered evidences of an increase in motivation and interest.

\section{The present study: objectives and hypotheses}

Due to the lack of motivation of Secondary Education students, partly because students believe that they are not intelligent enough to face the academic challenges of this educational stage, and taking into account the effectiveness and importance of brief interventions in the educational context (Yeager et al., 2013; Yeager y Walton, 2011), we wonder if a brief intervention, based on the theory of mindsets (Dweck, 1999) and other interventions related to this theory (Blackwell et al., 2007; Donohoe et al., 2012), modify 
students' mindsets? If it does, do these changes last for a month? This will allow us to know if the benefits of this intervention should be sought long or short term.

This research does not seek to demonstrate that this type of intervention improves academic performance, as this has already worked by other author (Blackwell et al., 2007; Paunesku et al., 2015; Yeager et al., 2016), but the objective of our research is to design an intervention that can be applied in the classroom to change the mindsets, thus producing an improvement of their motivation, or in other words, we want the students to think that we all have an intellectual potential and that It is up to us to work to develop it, instead of thinking that intelligence is innate and unchangeable. Our research hypothesis is that students' mindset after the intervention will be different between the group receiving the intervention (experimental) and the group that does not receive it (control), specifically we expect the experimental group to be characterized by a growth mindset.

\section{Method}

\section{Participants}

The participants of the study were 47 students of year 1 of Secondary Education from two high-schools in Gran Canaria (Spain).The experimental group consisted of 26 participants (13 female and 13 male) who belonged to one high-school, with a mean age of 13.13 years (standard deviation 0.53), whereas the control group consisted of 21 students ( 6 female and 15 male) who, in order to avoid possible contamination, studied in another nearby center with similar characteristics and a mean age of 13.19 years (standard deviation 0.54 ).

It should be clarified that the initial sample was comprised by 55 students, but it was observed that there were students diagnosed with specific educational needs support that did not understand the items of the questionnaire; for that reason, although they were present during the intervention, they were excluded from the study and their responses were not taken into account when analyzing the data. 


\section{Instruments}

To assess student mindsets, three items of the Dweck questionnaire (1999) were used on a Likert scale from 1 (totally disagree) to 7 (totally agree). The items used were: "A student can not change his intelligence easily", "A student has a certain amount of intelligence and can't do much to change it", "A student can learn new things, but can't really change the basic intelligence". This scale, both in its original version and in its reduced version of three items, has been used in previous studies with evidence of reliability and validity (Erdley and Dweck, 1993; Erdley, Loomis, Cain, Dumas-Hines and Dweck, 1997; 2014). To analyze the reliability, we used Cronbach's alpha. In this study in the first (T1), second (T2) and third (T3) time was $\alpha_{\mathrm{t} 1}=.77, \alpha_{\mathrm{t} 2}=.75 \& \alpha_{\mathrm{t} 3}=.84$.

\section{Procedure}

To analyze the efficacy of the intervention, we performed three evaluations using the described questionnaire. The first, two weeks before the start of the intervention, the second, after the intervention and the third, one month after the second evaluation. The experimental group and the control group came from different high-schools. These high-schools are close to each other, in addition, the profile of the students and teachers is similar. It was decided to choose groups of different high-schools to reduce the risk of contamination, that is, to reduce the risk that the students in the group receiving the intervention tell the group that does not receive the intervention what they worked.

The intervention was carried out in a 55-minute session and was divided into four parts. The specific purpose of the first part was to explain that the brain is like a muscle and as such, it can be exercised to improve performance. After the explanation, they were shown a fragment of television program (Redes, Televisión Española), which explained the need to put in shape the brain (www.youtube.com/watch? $\mathrm{v}=\mathrm{vw} 5 \mathrm{~L}-\mathrm{YNMewk}$ ). In the second part we explained that as we learn more connections are established between neurons, and that it is common in the brains of scientists like Albert Einstein or Marie Curie that there is a dense network of connected neurons. Also on this occasion, the explanation was illustrated with a TVE video (www.youtube.com / watch? $\mathrm{v}=\mathrm{JR} 4 \mathrm{gdLiuzQs}$ ) where it was explained in a very graphic way how when learning new connections are generated between neurons. In the third part of the session we talked about the IQ, and how this concept has ceased to be valid for many professionals and researchers because there is evidence that intelligence is not stable, but can be modified and, therefore, the result of our IQ, since it is not an immutable capacity, 
can be modified. Next, a piece of the Redes program was screened where the presenter interviewed an expert in the field, Shlomo Breznitz, on this topic (www.youtube.com/watch? $v=j U e i x 70 W P 3 Q)$. Finally, the goal of the fourth part was to consolidate. The students had to write a letter in a hypothetical situation: they had to imagine that years later, when studying in a high school, a friend or his partner told them that he or she wanted to stop studying because he did not feel intelligent enough to face the studies, and they had to convince him that he did not make that decision by referring to what he had learned during the session.

\section{Data analyses}

\section{Preliminary analysis}

First, for each of the students we computed the mean of the three items in each of the three assessments or moments. Then, to facilitate interpretation, we calculated the differential score, that is, from the average score of each subject in the three moments, we subtracted the large mean, which is the mean calculated taking into account all scores of the sample in the three evaluations. The mean score and the standard deviation of the experimental and control groups were calculated in each of the three evaluations. Two unilateral contrasts were performed using a T-Student for paired samples to subjects in the experimental group: first, to analyze whether after the intervention, the decrease in the dependent variable had been significantly different from zero, and the second, to analyze whether the dependent variable was raised again in the third evaluation. Likewise, two contrasts of bilateral hypotheses were made, also using a T-Student for paired subjects in the control group, in order to analyze if there were significant differences between the first and second evaluation, and between the latter and the third. Finally, as an indicator of effect size, Cohen's d was calculated on each comparison of means.

\section{Multilevel analysis}

Then, to analyze whether the efficacy of the intervention, a multilevel analysis was performed, which, unlike the repeated measures ANOVA, offers four advantages: 1) the time between evaluations does not have to be the same, 2) it is not necessary to eliminate subjects with data lost in any of the evaluations, 3) does not require equality in the variances of each evaluation, 4) nor does it require equality in the covariance between evaluations (Kwok et al., 2008). 
To analyze which part of the total variability of the three evaluations was due to differences between the participants, we calculated the intraclass correlation coefficient (ICC), which measures the relationship between the variability of the individual scores of each subject and the total variability of all study subjects. To obtain evidence that the intervention has been effective, it must be demonstrated that the subjects of both groups follow different trajectories. In this case, the data followed curvilinear trajectories, so a multilevel model of quadratic growth was constructed with the group (control and experimental) as covariate, with the following function: $Y_{t i}=\gamma_{0 i}+\gamma_{1 i}$ time $+\gamma_{2 i}$ time ${ }^{2}+$ $\gamma_{3 i}$ group $+\gamma_{4 \mathrm{i}}$ time-group $+\gamma_{5 \mathrm{i}} \cdot$ time $^{2}$.group. Because the sample size was small, the estimation method used was the restricted maximum likelihood.

Finally, in order to analyze the extent to which the intervention was effective (effect size), the Pseudo R square was calculated, which measures the proportion of variance explained by the covariate, that is, it measures what percentage of the variability of the trajectories of each subject is due to the intervention. To calculate the Pseudo R squared we compared the variance between subjects of the model with covariable, with the variance between subjects of the model without taking into account the covariable group. The data analyzes were performed with SPSS software 22.

\section{Results}

\section{Preliminary analysis}

In Table 1 we can observe the mean of the differential scores of the two groups in the three evaluations. By paying attention to the experimental group data, if we compare the first with the second evaluation, we can see that the fix mindset decreases after the intervention, $t$ $(22)=-1.66, p=.05, \mathrm{~d}=.32$, but increases in the third time $(\mathrm{t}(23)=-1.79, p=.04, \mathrm{~d}=.39)$. However, in the control group there were no significant differences between the first and second evaluation $\mathrm{t}(20)=-.88, p=.19, \mathrm{~d}=.18$, nor between the second and third evaluation $(\mathrm{t}$ $(20)=-1.07, \mathrm{p}=.15, \mathrm{~d}=.13)$. 
Table 1

Mean score and standard deviation per group and evaluation

\begin{tabular}{lcccccc}
\hline \multirow{2}{*}{ Group } & \multicolumn{7}{c}{ Evaluation } \\
& \multicolumn{2}{c}{1} & \multicolumn{2}{c}{2} & \multicolumn{2}{c}{3} \\
& $\mathrm{M}$ & $\mathrm{DT}$ & $\mathrm{M}$ & $\mathrm{DT}$ & $\mathrm{M}$ & $\mathrm{DT}$ \\
Experimental & .04 & 1.53 & -.44 & 1.51 & .04 & 1.57 \\
Control & .02 & 1.70 & .32 & 1.61 & .11 & 1.59 \\
\hline
\end{tabular}

\section{Multinivel analysis}

ICC was .50 , that is, $50 \%$ of the total variability over the three evaluations was due to differences between participants and the other $50 \%$ due to intrapersonal differences. Table 2 shows the parameters of the function and its level of significance. Substituting the parameters in the function described in the section of data analysis, we obtain: $\mathrm{Y}_{\mathrm{ti}}=4.29+(-5.54) \cdot$ time $+1.36 \cdot$ time $2+(-2.55) \cdot$ group $+3.30 \cdot$ time $\cdot$ group $+(-0.81 \cdot$ time $2 \cdot$ group $)$.

\section{Tabla 2}

Parameters of the multilevel model

\begin{tabular}{cccc}
\hline & Parameter Standard error & $p$ \\
\hline Fixed effects & & & \\
Intercept $\left(\gamma_{0 \mathrm{i}}\right)$ & 4.29 & 2.07 & .00 \\
Time $\left(\gamma_{1 \mathrm{i}}\right)$ & -5.54 & 2.24 & .02 \\
Time ${ }^{2}\left(\gamma_{2 \mathrm{i}}\right)$ & 1.36 & .55 & .02 \\
Group $\left(\gamma_{3 \mathrm{i}}\right)$ & -2.55 & 1.34 & .06 \\
Time·Group $\left(\gamma_{4 \mathrm{i}}\right)$ & 3.30 & 1.44 & .03 \\
Time & \\
Random Group $\left(\gamma_{5 \mathrm{i}}\right)$ & -.81 & .35 & .03 \\
$\sigma^{2}$ within-subjects & & & \\
$\sigma^{2}$ between-subjects $\left(\tau_{00}\right)$ & 0.93 & & \\
\hline
\end{tabular}

Through the multilevel analysis it was observed that the trajectory of the experimental group was different from that of the control group, since the interaction between the variable time squared and group was significant, $p=.03$, and the size of the effect, calculated using the Pseudo R squared, was.09, which implies that the intervention had an average effect. 
Figure 1 display the trajectories of each group via the scores estimated using the previously described function. It can be observed that in the experimental group the score of the dependent variable decreases after the intervention, but it recovers with the passage of time. However, the score of the control group did not decrease between the first and second evaluation and, although it may appear to have increased at first glance, this difference, as described in the preliminary analysis section, was not significant $(\mathrm{t}(20)=-.88, p=.19)$.

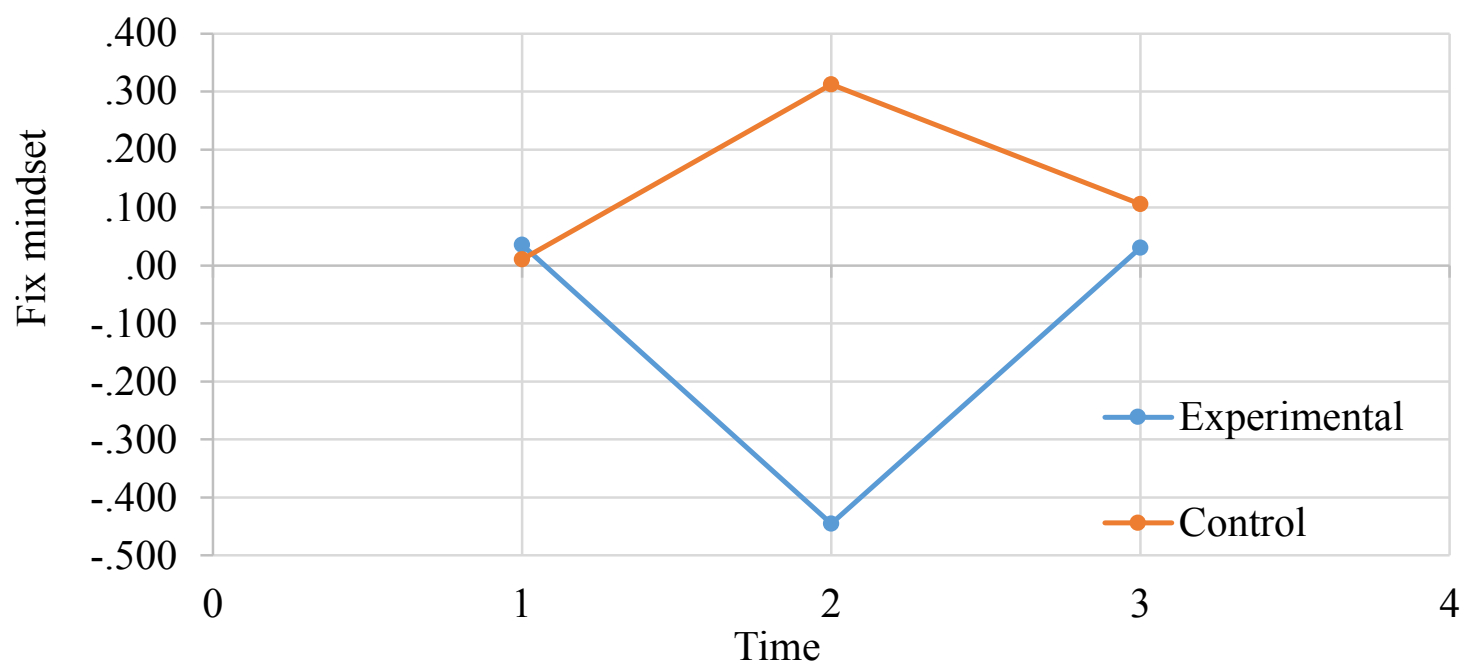

Figure 1. Estimated scores by group and time

\section{Discussion and conclusions}

The objective of this work was to analyze the effectiveness of an intervention so that the students of Secondary Education thought in the intelligence like something that can be modified. We hypothesized that the experimental group would modify their mindsets after the intervention. Our hypothesis was partially fulfilled, since, although the results after the intervention showed that the objective had been achieved, that is, the experimental group changed its idea about intelligence, thinking of it as a modifiable capacity, however, a month after the intervention the group returned to their initial ideas.

The results of this work are in line with those obtained by Donohoe et al. (2012), who observed that, although the intervention had been effective, with the passage of time the effects of the intervention were fading, since the students returned to think of intelligence as before the intervention. If we take into account the results of the intervention performed by Blackwell et al. (2007), it should be noted that the dependent variable in this study (the grades 
of the Mathematics subject) was evaluated differently, since two previous measures were taken and only one after the intervention, so the question arises: If over time the effect of the intervention would have faded. Following the results of our study and those obtained by Donohoe et al. (2012), it seems obvious that in this type of brief interventions it is necessary to dedicate some time to consolidate what worked with students. It seems that these brief interventions may not be effective in a continuous way over time, but in specific moments, for example, in an examination period, since at this time, feelings of incompetence increase, especially in students with low performance. It is also remarkable the increase in the fixed mindset in the control group. Other longitudinal studies that have analyzed mindsets or goal orientations have not observed such high variability (Martin, 2015, Martin and Liem, 2010), and the period between evaluations of these studies has been greater than ours. Therefore, it is possible that this variability, which was not significant, is due simply to chance, even so, we consider that it would be interesting to carry out longitudinal studies to know the path of the mindsets.

In this paper, we want to name some limitations and propose ideas for future studies. Firstly, although a design with a quasi-experimental group and a quasi-control group has been used, which increases the validity of the study in comparison to a pre-post design of a single group, we must point out that, just as happens in other similar studies (Donohoe et al., 2012; Blackwell et al., 2007; McGinley and Jones, 2014), the number of subjects per group was small, so we need to be cautious when making inferences. Second, future research could test the effect of reinforcements, weekly, biweekly or monthly, and analyze whether the change in students' mindsets is maintained or returned to its original state.

Thirdly, as a future perspective, we believe that it would be interesting to analyze if the effectiveness of this intervention would be greater if applied in students who feel inferior or less capable than their peers. This idea stems from by Davis, Burnette, Allison and Stone (2010) who observed that a growth mindset was key when students, in a mathematical competition, believed that they were less capable than the rest of their peers. Also, Chen and Pajares (2010) point out that a growth mindset is important when students begin to lower their performance, so future research could analyze whether this intervention would be more effective in students who have seen their Academic performance or with immigrant students since the risk of school failure is higher (Sandín-Esteban and Sánchez-Martí, 2015). Fourth, it should be noted that in this study we used a selection of items from the instrument to evaluate the perception about intelligence, although we provide evidence of reliability and, we 
consider that the items adequately represent the construct to be evaluated, it could be that the results with other items were somewhat different.

Finally, we want to emphasize that with this work we have contributed to increase the knowledge of brief interventions in the educational context (Yeager et al., 2013; Yeager and Walton, 2011), useful for reducing academic demotivation, a very important problem in the current educational system (González and Paoloni, 2015, OECD, 2012). In this work, we designed a brief intervention that modified a motivational component with a strong relation with academic functioning (Blackwell et al.., 2007), and what stands out is that it can serve as a starting point for future research to improve academic performance in a simple, replicable and easily scalable. 


\section{References}

Anderman, L. H. (2003). Academic and social perceptions as predictors of change in middle school students' sense of school belonging. The Journal of Experimental Education, 72(1), 5-22. doi:10.1080/00220970309600877

Aronson, J., Fried, C. B., \& Good, C. (2002). Reducing the effects of stereotype threat on African American college students by shaping theories of intelligence. Journal of Experimental Social Psychology, 38(2), 113-125. doi:10.1006/jesp.2001.1491

Blackwell, L. S., Trzesniewski, K. H., \& Dweck, C. S. (2007). Implicit theories of intelligence predict achievement across an adolescent transition: A longitudinal study and an intervention. Child Development, 78(1), 246-63. doi:10.1111/j.14678624.2007.00995.x

Chen, J. A., \& Pajares, F. (2010). Implicit theories of ability of Grade 6 science students: Relation to epistemological beliefs and academic motivation and achievement in science. $\begin{array}{llll}\text { Contemporary } & \text { Educational } & \text { Psychology, } & \text { 35(1), }\end{array}$ doi:10.1016/j.cedpsych.2009.10.003

Cohen, G. L., Garcia, J., Purdie-Vaughns, V., Apfel, N., \& Brzustoski, P. (2009). Recursive processes in self-affirmation: Intervention to close the minority achievement gap. Science, 324, 400-403.

Cordero, J. M., \& Manchón, C. (2014). Explanatory factors for achievement in primary education: An analysis using timss 2011. Estudios Sobre Educación, 27, 9-35. doi:10.15581/004.27.9-35

Crane, C. A., \& Eckhardt, C. I. (2013). Evaluation of a single-session brief motivational enhancement intervention for partner abusive men. Journal of Counseling Psychology, 60(2), 180-7. doi:10.1037/a0032178

Davidson, A. J., Gest, S. D., \& Welsh, J. A. (2010). Relatedness with teachers and peers during early adolescence: An integrated variable-oriented and person-oriented approach. Journal of School Psychology, 48(6), 483-510. doi:10.1016/j.jsp.2010.08.002

Davis, J. L., Burnette, J. L., Allison, S. T., \& Stone, H. (2010). Against the odds: Academic underdogs benefit from incremental theories. Social Psychology of Education, 14(3), 331-346. doi:10.1007/s11218-010-9147-6

Donohoe, C., Topping, K., \& Hannah, E. (2012). The impact of an online intervention (Brainology) on the mindset and resiliency of secondary school pupils: a preliminary 
mixed methods study. Educational Psychology, 32(5), 641-655. doi:10.1080/01443410.2012.675646

Dweck, C. S. (1999). Self-theories: Their role in motivation, personality, and development. Philadelphia: Psychology Press.

Dweck, C. S. (2006). Mindset: The new psychology of success. New York: Random House.

Dweck, C. S., \& Leggett, E. (1988). A social-cognitive approach to motivation and personality. Psychological Review, 95(2), 256-273. Retrieved from http://psycnet.apa.org/journals/rev/95/2/256/

Eccles, J. S. (1983). Expectancies, values, and academic behaviours. En J. T. Spence (Ed.), Achievement and achievement motives (pp. 75-146). San Diego, CA: Freeman.

Erdley, C. A., \& Dweck, C. S. (1993). Children's implicit personality theories as predictors of their social judgments. Child Development, 64(3), 863-78.

Erdley, C. A., Loomis, C. C., Cain, K. M., Dumas-Hines, F., \& Dweck, C. S. (1997). Relations among children's social goals, implicit personality theories, and responses to social failure. Developmental Psychology, 33(2), 263-272. doi:10.1037//00121649.33 .2 .263

González, A., \& Paoloni, P. (2015). Implicación y rendimiento en Física: el papel de las estrategias docentes en el aula, y el interés personal y situacional del alumnado. Revista de Psicodidáctica, 20(1), 25-45. doi:10.1387/RevPsicodidact.11370

Goodenow, C. (1993). Classroom belonging among early adolescent students: Relationships to motivation and achievement. The Journal of Early Adolescence, 13(1), 21-43.

Hong, Y., Chiu, C., Dweck, C. S., Lin, D. M.-S., \& Wan, W. (1999). Implicit theories, attributions, and coping: A meaning system approach. Journal of Personality and Social Psychology, 77(3), 588-599. doi:10.1037//0022-3514.77.3.588

Hulleman, C. S., \& Harackiewicz, J. M. (2009). Promoting interest and performance in high school science classes. Science, 326(5958), 1410-1412. doi:10.1126/science.1177067

Inglés, C. J., Martínez-Monteagudo, M. C., García-Fernández, J. M., Valle, A., Núñez, J. C., Delgado, B., \& Torregrosa, S. (2015). Motivational profiles Spanish students of compulsory secondary education: differential analysis of academic self-attributions. Anales de Psicología, 31(2), 579-588.

Kwok, O.-M., Underhill, A. T., Berry, J. W., Luo, W., Elliot, T. R., \& Yoon, M. (2008). Analyzing longitudinal data with multilevel models: An example with individuals living with lower extremity intra-articular fractures. Rehabilitation Psychology, 53(3), 370386. doi:10.1037/a0012765 
Lazowski, R. A., \& Hulleman, C. S. (2016). Motivation interventions in education: A metaanalytic review. Review of Educational Research, (En prensa). doi: $10.3102 / 0034654315617832$

Lim, M., Tormshak, E. a. S., \& Dishion, T. J. (2005). A one-session intervention for parents of young adolescents: Videotape modeling and motivational group discussion. Journal of Emotional and Behavioral Disorders, 13(4), 194-199. doi:10.1177/10634266050130040101

Locke, E. A., \& Latham, G. P. (1990). A theory of goal setting and task performance. Englewood Cliffs, NJ: Prentice Hall.

Locke, E. A., \& Latham, G. P. (2002). Building a practically useful theory of goal setting and task motivation: A 35-year odyssey. American Psychologist, 57(9), 705-717. doi:10.1037//0003-066X.57.9.705

Luo, W., Lee, K., Ng, P. T., \& Wei Ong, J. X. (2014). Incremental beliefs of ability, achievement emotions and learning of Singapore students. Educational Psychology, 34(5), 619-634. doi:10.1080/01443410.2014.909008

Martin, A. J. (2015). Implicit theories about intelligence and growth (personal best) goals: Exploring reciprocal relationships. British Journal of Educational Psychology, 85(2), 207-223. doi:10.1111/bjep.12038

Martin, A. J., \& Liem, G. A. D. (2010). Academic personal bests (PBs), engagement, and achievement: A cross-lagged panel analysis. Learning and Individual Differences, 20(3), 265-270. doi:10.1016/j.lindif.2010.01.001

McGinley, J. J., \& Jones, B. D. (2014). A brief instructional intervention to increase students' motivation on the first day of class. Teaching of Psychology, 41(2), 158-162. doi:10.1177/0098628314530350

Morisano, D., Hirsh, J. B., Peterson, J. B., Pihl, R. O., \& Shore, B. M. (2010). Setting, elaborating, and reflecting on personal goals improves academic performance. The Journal of Applied Psychology, 95(2), 255-64. doi:10.1037/a0018478

OCDE. (2012). Orientaciones de PISA para las Islas Canarias, España: Sistemas fuertes y reformadores exitosos en la educación. OECD Publishing. doi:10.1787/9789264174788es

Paunesku, D., Walton, G. M., Romero, C., Smith, E. N., Yeager, D. S., \& Dweck, C. S. (2015). Mind-set interventions are a scalable treatment for academic underachievement. Psychological Science, 26(6), 784-793. doi: 10.1177/0956797615571017 
Rattan, A., Good, C., \& Dweck, C. S. (2012). "It's ok - Not everyone can be good at math": Instructors with an entity theory comfort (and demotivate) students. Journal of Experimental Social Psychology, 48(3), 731-737. doi:10.1016/j.jesp.2011.12.012

Roeser, R. W., \& Eccles, J. S. (1998). Adolescents' perceptions of middle school: relation to longitudinal changes in academic and psychological adjustment. Journal of Research on Adolescence, 8(1), 123-158. doi:10.1207/s15327795jra0801_6

Romero, C., Master, A., Paunesku, D., Dweck, C. S., \& Gross, J. J. (2014). Academic and emotional functioning in middle school: The role of implicit theories. Emotion, 14(2), 227-234. doi:10.1037/a0035490

Sandín-Esteban, M. P., \& Sánchez-Martí, A. (2015). Resilience and school success of young immigrants. Infancia y Aprendizaje: Journal for the Study of Education and Development, 38(1), 209-211. doi:10.1080/02103702.2015.1009232

Spitzer, B., \& Aronson, J. (2015). Minding and mending the gap: Social psychological interventions to reduce educational disparities. British Journal of Educational Psychology, 85, 1-18. doi:10.1111/bjep.12067

Thurstone, C., Riggs, P. D., Klein, C., \& Mikulich-Gilbertson, S. K. (2007). A one-session human immunodeficiency virus risk-reduction intervention in adolescents with psychiatric and substance use disorders. Journal of the American Academy of Child \& Adolescent Psychiatry, 46(9), 1179. doi:10.1097/chi.0b013e31809fe774

Verniers, C., \& Martinot, D. (2015). Perception of students' intelligence malleability and potential for future success: Unfavourable beliefs towards girls. British Journal of Educational Psychology, in press. doi:10.1111/bjep.12073

Walton, G. M., \& Cohen, G. L. (2011). A brief social-belonging intervention improves academic and health outcomes of minority students. Science, 331, 1447-1451.

Wentzel, K. R. (2009). Peers and academic functioning at school. En K. H. Rubin, W. M. Bukowski, \& B. Laursen (Eds.), Handbook of peer interactions, relationships, and groups (pp. 531-547). New York, US: The Guilford Press.

Wigfield, A., \& Eccles, J. S. (2000). Expectancy-value theory of achievement motivation. Contemporary Educational Psychology, 25(1), 68-81. doi:10.1006/ceps.1999.1015

Yeager, D. S., Johnson, R., Spitzer, B. J., Trzesniewski, K. H., Powers, J., \& Dweck, C. S. (2014). The far-reaching effects of believing people can change: implicit theories of personality shape stress, health, and achievement during adolescence. Journal of Personality and Social Psychology, 106(6), 867-884. doi:10.1037/a0036335 
Yeager, D. S., Paunesku, C., Dave, R., Hulleman, C. S., Schneider, B., Hinojosa, C., ... Dweck, C. S. (2016). Designing social-psychological interventions for full-scale implementation: The case of the growth mindset during the transition to high school. Journal of Educational Psychology, 108(3), 374-391. doi: 10.1007/s13398-014-0173-7.2

Yeager, D. S., \& Walton, G. M. (2011). Social-Psychological interventions in education: They're not magic. Review of Educational Research, 81(2), 267-301. doi:10.3102/0034654311405999

Yeager, D. S., Walton, G. M., \& Cohen, G. L. (2013). Addressing achievement gaps with psychological interventions. Phi Delta Kappan, 94(5), 62-65. 
Improving the perception of intelligence: a short intervention for Secondary School Students

[This page intentionally left blank] 